\title{
Genetic diversity analysis among pigeonpea genotypes adapted to South American regions based on microsatellite markers
}

\author{
Adna Cristina Barbosa de Sousa ${ }^{1}$, Rodolfo Godoy ${ }^{2}$, Danilo Augusto Sforça ${ }^{1}$, Tatiana de Campos ${ }^{1}$, \\ Maria Imaculada Zucchi ${ }^{3}$, Liana Jank ${ }^{4}$, Anete Pereira de Souza ${ }^{1,5 *}$ \\ ${ }^{1}$ UNICAMP/Centro de Biologia Molecular e Engenharia Genética, C.P. 6010 - 13083-970 - Campinas, SP - \\ Brasil. \\ ${ }_{3}^{2}$ EMBRAPA Pecuária Sudeste, Rod. Washington Luiz, SP-310 - 13566-684 - São Carlos, SP - Brasil. \\ ${ }^{3}$ IAC - Pólo Apta Sul, Rod. SP 127, km 30, C.P. 28 - 13400-970 - Piracicaba, SP - Brasil. \\ ${ }^{4}$ EMBRAPA Gado de Corte - Lab. de Biotecnologia de Plantas, C.P. 154 - 79002-970 - Campo Grande, MS - \\ Brasil. \\ 'UNICAMP/Inst. de Biologia - Depto. de Biologia Vegetal, C.P. 6109 - 13083-970 - Campinas, SP - Brasil. \\ *Corresponding author < anete@unicamp.br> \\ Edited by: Leonardo Oliveira Medici
}

\begin{abstract}
The pigeonpea [Cajanus cajan (L) Millspaugh] is one of the most important perennial legume crops utilized in the food, fodder, soil conservation, crop-livestock integrated systems, reclaiming of degraded pastures and symbiotic nitrogen fixation. Microsatellite markers were used to estimate the genetic diversity of 77 pigeonpea genotypes selected from the germplasm collections at Embrapa Cattle-Southeast and, to evaluate their transferability to Phaseolus vulgaris and Vigna unguiculata species. The number of alleles per locus ranged from 2 to12, with an average of 5.1 alleles. The PIC values ranged from 0.11 to 0.80 (average 0.49 ) and the $D$ values from 0.23 to 0.91 (average 0.58 ). The averages of observed and expected heterozygosity were 0.25 and 0.47 , respectively, showing a deficit in heterozygosity. A model-based Bayesian approach implemented in the software STRUCTURE was used to assign genotypes into clusters. A dendrogram was constructed based on the modified Roger's genetic distances using a neighbor-joining method (NJ). A total of four clusters were assembled by STRUCTURE and a strong tendency of correspondence between the Bayesian clusters in the NJ tree was observed. The genetic distance ranged from 0.09 to 0.62 (average 0.37 ), showing a low genetic diversity in the pigeonpea genotypes. Transferability of pigeonpea-specific microsatellites revealed a cross-amplification and the presence of polymorphic alleles in $P$. vulgaris and $V$. unguiculata.
\end{abstract}

Keywords: legumes, transferability, microsatellite, germplasm

\section{Introduction}

The pigeonpea [Cajanus cajan (L.) Millspaugh] is one of the most important perennial legume crops in the tropic and subtropic regions of the world. Because of its multiple usages in food, fodder, soil conservation, crop-livestock integrated systems, reclaiming of degraded pastures and symbiotic nitrogen fixation, the pigeonpea plays an important role in subsistence agriculture (Reddy et al., 2005).

Because of the potential of the pigeonpea as a forage legume, the Brazilian Agricultural Research Corporation (Embrapa Cattle-Southeast, state of São Paulo-SP) has germplasm collections of selected genotypes with desirable agronomic traits such as high yield, quality of forage and lowest tannin content (Godoy et al., 1995). Over time, the selected genotypes showed phenotypic segregation in subsequent generations. Therefore, these genotypes were self-fertilized and subsequently selected in order to obtain inbred lines (Godoy et al., 1994, 1997). Several studies have been conducted to characterize genotypes and inbred lines of the pigeonpea and provide basic information for breeding. The genetic variability of a partial set of accessions from this collection was assessed using Random Amplification of Polymorphic DNA (RAPD) molecular markers. Results showed low genetic variability and the need to broaden the genetic base for use in crop-livestock integrated systems and reclaiming degraded pastures (Godoy et al., 2003)

The knowledge of the genetic variability is very important in for pigeonpea germplasm collections and pigeonpea breeding programs. Microsatellite markers are quite effective for estimating genetic diversity and genetic relationships and in predicting the genetic value of selected genotypes derived from intraspecific crosses and the performance of their hybrid progenies (Gaitán-Solís et et al., 2002; Varshney et al., 2005). In this study, we used 43 microsatellite markers to evaluate the genetic diversity of 77 pigeonpea selected genotypes from the Embrapa collection. In addition, we studied cross-species amplification in Phaseolus vulgaris L. and Vigna unguiculata L. Walp.

\section{Materials and Methods}

We have selected 43 microsatellite markers described in the literature (Burns et al., 2001; Odeny et al., 2007) to analyze 77 pigeonpea genotypes (Table 1) of the Brazilian Agricultural Research Corporation (Embrapa CattleSoutheast) germplasm collection, in São Carlos, SP, Brazil. Thirty-nine of them are Brazilian inbred lines, three are commercial cultivars and thirty-five came from the International Crops Research Institute for the Semi-Arid 
Table 1 - Characteristics of 43 pigeonpea microsatellite markers.

\begin{tabular}{|c|c|c|c|c|c|c|c|}
\hline $\begin{array}{l}\text { GenBank } \\
\text { Accession no. }\end{array}$ & $\begin{array}{l}\text { Repeat } \\
\text { Motif }\end{array}$ & Primer Sequences $\left(5^{\prime}\right.$ - 3') & $\begin{array}{l}{ }^{(3)} \mathrm{Ta} \\
\left({ }^{\circ} \mathrm{C}\right) \\
\end{array}$ & $\begin{array}{c}\text { Product } \\
\text { Length (bp) }\end{array}$ & $\begin{array}{c}\text { Polymorphic } \\
\text { Markers }\end{array}$ & $\begin{array}{c}\text { Monomorphic } \\
\text { Markers }\end{array}$ & Source \\
\hline \multirow[t]{2}{*}{ CZ445531 } & $(\mathrm{TA})_{11}$ & ${ }^{(1)} \mathrm{F}:$ TGAATTGCTGAGAGGACGTTT & 56 & $234-238$ & + & - & Odeny et al. (2007) \\
\hline & & (2)R: CTGTTCCAATTCCACGGTTT & & & & & \\
\hline \multirow[t]{2}{*}{ CZ445540 } & $(\mathrm{GGT})_{4}$ & F: ACGCTTCTGATGCTGTGTTG & 45 & $208-210$ & + & - & Odeny et al. (2007) \\
\hline & & R: CATCAGCATCATCGTTACCC & & & & & \\
\hline \multirow[t]{2}{*}{ CZ445530 } & $(\mathrm{TTC})_{5}$ & F: CCATTGTGCGTCTTTGTGTT & 56 & $206-208$ & + & - & Odeny et al. (2007) \\
\hline & & R: GCTTTTCCTCTTCCTTTCTCG & & & & & \\
\hline \multirow[t]{2}{*}{ AJ306901 } & $(\mathrm{CA})_{10}$ & F: AAGGGTTGTATCTCCGCGTG & 56 & $186-202$ & + & - & Burns et al. (2001) \\
\hline & & R: GCAAAGCAGCAATCATTTCG & & & & & \\
\hline \multirow[t]{2}{*}{$\mathrm{AJ} 312887$} & $(\mathrm{CA})_{21}$ & F: CCATAATCCAATCCAAATCC & 51 & $160-170$ & + & - & Burns et al. (2001) \\
\hline & & R: AGAAGGCTTTCATGTAACGC & & & & & \\
\hline \multirow[t]{2}{*}{ AJ312891 } & $(\mathrm{CA})_{6}$ & F: ACAATGCTAGGGAACACCGC & 45.5 & $180-206$ & + & - & Burns et al. (2001) \\
\hline & & R: TACCTTAACCCACAATGGCC & & & & & \\
\hline \multirow[t]{2}{*}{$\mathrm{AJ} 312892$} & $(\mathrm{CT})_{16}$ & F: CAACATTTGGACTAAAAACTG & 56 & $150-158$ & + & - & Burns et al. (2001) \\
\hline & & R: AGGTATCCAATATCCAACTTG & & & & & \\
\hline \multirow[t]{2}{*}{ AJ312893 } & $(\mathrm{CT})_{30}$ & F: TGCGTTTGTAAGCATTCTTCA & 50 & $126-150$ & + & - & Burns et al. (2001) \\
\hline & & R: ACTTGAGGCTGAATGGATTTG & & & & & \\
\hline \multirow[t]{2}{*}{$\mathrm{AJ} 312894$} & $(\mathrm{CT})_{22}$ & F: CACTTGGTTGGCTCAAGAAC & 45 & $152-180$ & + & - & Burns et al. (2001) \\
\hline & & R: GCCAATGAACTCACATCCTTC & & & & & \\
\hline \multirow[t]{2}{*}{ AJ312895 } & $(\mathrm{CA})_{15}$ & F: CCTTCTTAAGGTGAAATGCAAGC & 45 & $228-242$ & + & - & Burns et al. (2001) \\
\hline & & R:ATAACAATAAAAGACCTTGAATGC & & & & & \\
\hline \multirow[t]{2}{*}{ CZ681930 } & $(\mathrm{TC})_{8}$ & F: GCGCTAAGGGAAAACAAAAA & 56 & $164-174$ & + & - & Odeny et al. (2007) \\
\hline & & R: AACTCCCTTGTTGTCATATGGTG & & & & & \\
\hline \multirow[t]{2}{*}{ CZ681938a } & $(\mathrm{ATT})_{21}$ & F: TCAGGGGTAAATGCGGTATC & 50 & $236-260$ & + & - & Odeny et al. (2007) \\
\hline & & R: GAATTGCTTTTTGCTTCCTCA & & & & & \\
\hline \multirow[t]{2}{*}{ CZ681938b } & $(\mathrm{ATT})_{21}$ & F: TCAGGGGTAAATGCGGTATC & 50 & $212-234$ & + & - & Odeny et al. (2007) \\
\hline & & R: GAATTGCTTTTTGCTTCCTCA & & & & & \\
\hline \multirow[t]{2}{*}{ CZ682017a } & $(\mathrm{AAG})_{13}$ & F: TGAAATGAACAAACCTCAATGG & 45 & $200-222$ & + & - & Odeny et al. (2007) \\
\hline & & R: TGTATTGCACATTGACTTGGCTA & & & & & \\
\hline \multirow[t]{2}{*}{ CZ682017b } & $(\mathrm{AAG})_{13}$ & F: TGAAATGAACAAACCTCAATGG & 45 & $174-182$ & + & - & Odeny et al. (2007) \\
\hline & & R: TGTATTGCACATTGACTTGGCTA & & & & & \\
\hline \multirow[t]{2}{*}{ CZ681983 } & $(\mathrm{TGA})_{11}$ & F: GAGGAGGAGGAAGAAGAAGAAGA & 45.5 & $73-79$ & + & - & Odeny et al. (2007) \\
\hline & & R: TCGTCGCCGTATCACTACAA & & & & & \\
\hline \multirow[t]{2}{*}{ CZ445530 } & $(\mathrm{TTC})_{5}$ & F: CGGGCTTCCTTTTCTTCTCT & 46 & 200 & - & + & Odeny et al. (2007) \\
\hline & & R: AAAACCCCGAAAACACCATT & & & & & \\
\hline \multirow[t]{2}{*}{ CZ445525 } & $(\mathrm{TTA})_{10}$ & F: TTCTGGATCCCTTTCATTTTTC & 45 & 196 & - & + & Odeny et al. (2007) \\
\hline & & R: TGACACCCTTCTACCCCATAA & & & & & \\
\hline \multirow[t]{2}{*}{ CZ445522 } & $(\mathrm{TA})_{8}$ & F: CTTCCCCCAACTAAGATCCA & 46 & 212 & - & + & Odeny et al. (2007) \\
\hline & & R: GTTCGTTCTCTTTAATTGACTTGC & & & & & \\
\hline
\end{tabular}


Table 1-Continuation.

\begin{tabular}{|c|c|c|c|c|c|c|c|}
\hline \multirow[t]{2}{*}{ CZ445538 } & $(\mathrm{TTA})_{4}$ & F: CCAAGAAAAGGTGCTCCAAGT & 45.5 & 155 & - & + & Odeny et al. (2007) \\
\hline & & R: TTGCTTCTTTTCTCGCTTGC & & & & & \\
\hline \multirow[t]{2}{*}{ CZ445539 } & $(\mathrm{CAT})_{4}$ & F: TGATAGGGACCACAACGACA & 56 & 200 & - & + & Odeny et al. (2007) \\
\hline & & R: AGCGTTGACTCCTCCCTCTT & & & & & \\
\hline \multirow[t]{2}{*}{ CZ445519 } & $\begin{array}{l}\text { (CT)6TT } \\
(\mathrm{CT})_{2}\end{array}$ & F: GACTCTTСАССТСАСАСТСАТСАС & 46 & 190 & - & + & Odeny et al. (2007) \\
\hline & & R: ACCTCATACAACAACCCTAAGCAC & & & & & \\
\hline \multirow[t]{2}{*}{ CZ445544 } & $\left(\right.$ TTAT $_{4}$ & F: TACAGCAGCCACATCAAAGC & 45.5 & 290 & - & + & Odeny et al. (2007) \\
\hline & & R: TGAACCGTGAAAGTGGGATT & & & & & \\
\hline \multirow[t]{2}{*}{ CZ445553 } & $(\mathrm{TTA})_{4}$ & F: ACCCATTATTGATTTGGGTA & 45.5 & 200 & - & + & Odeny et al. (2007) \\
\hline & & R: CCAAATTTCACCCAAGAAA & & & & & \\
\hline \multirow[t]{2}{*}{ CZ445545 } & $(\mathrm{AAT})_{4}$ & F: TCTTCCATTGCATGGTGTT & 56 & 202 & - & + & Odeny et al. (2007) \\
\hline & & R: GCATGATATGAGATGATGACGA & & & & & \\
\hline \multirow[t]{2}{*}{ CZ445554 } & $(\mathrm{AAC})_{4}$ & F: ATAGGCCCATCTCCAGGTTC & 47 & 158 & - & + & Odeny et al. (2007) \\
\hline & & R: TTAATGCCCAGCCAATTCTT & & & & & \\
\hline \multirow[t]{2}{*}{ CZ445553 } & $(\mathrm{TTA})_{4}$ & F: ACCCATTATTGATTTGGGTA & 45.5 & 200 & - & + & Odeny et al. (2007) \\
\hline & & R: CCAAATTTCACCCAAGAAA & & & & & \\
\hline \multirow[t]{2}{*}{ CZ445545 } & $(\mathrm{AAT})_{4}$ & F: TCTTCCATTGCATGGTGTT & 56 & 202 & - & + & Odeny et al. (2007) \\
\hline & & R: GCATGATATGAGATGATGACGA & & & & & \\
\hline \multirow[t]{2}{*}{ CZ445554 } & $(\mathrm{AAC})_{4}$ & F: ATAGGCCCATCTCCAGGTTC & 47 & 158 & - & + & Odeny et al. (2007) \\
\hline & & R: TTAATGCCCAGCCAATTCTT & & & & & \\
\hline \multirow[t]{2}{*}{ CZ445521 } & $\begin{array}{l}(\mathrm{TA})_{4}(\mathrm{AT})_{4} \\
(\mathrm{AT})_{4}\end{array}$ & 4F: CTACAATCCCAGGGAAAAGG & 46 & 210 & - & + & Odeny et al. (2007) \\
\hline & & R: ACAAACGTAATCTGTGTTGATCTC & & & & & \\
\hline \multirow[t]{2}{*}{ CZ681935 } & $(\mathrm{TC})_{8}$ & F: CATTTATTTCTCTCTGGCATTCAC & 56 & 158 & - & + & Odeny et al. (2007) \\
\hline & & R: CGAGCTGCAAGCATAAACG & & & & & \\
\hline \multirow[t]{2}{*}{ CZ681923 } & $(\mathrm{AAG})_{5}$ & F: CATCGCCTACAATCATACAAAGA & 54 & 106 & - & + & Odeny et al. (2007) \\
\hline & & R: TCTTGTCCTTTTTCAGTCATCGT & & & & & \\
\hline \multirow[t]{2}{*}{ CZ681927 } & $(\mathrm{GAA})_{16}$ & F: CTCTTGCTTACGCGTGGACT. & 45.5 & 206 & - & + & Odeny et al. (2007) \\
\hline & & R: CTTTTGCTTTTGGGTGCTT & & & & & \\
\hline \multirow[t]{2}{*}{ CZ681929 } & $(\mathrm{AGA})_{5}$ & F: TCACAGAGGACCACACGAAG & 50 & 200 & - & + & Odeny et al. (2007) \\
\hline & & R: TGGACTAGACATTGCGTGAAG & & & & & \\
\hline \multirow[t]{2}{*}{ CZ681933 } & $(\mathrm{AGA})_{4}$ & F: AGAGGGAAAGGGAAGAGAAGA & 54 & 200 & - & + & Odeny et al. (2007) \\
\hline & & R: TCAAGCAACTCCAAGAAATTCA & & & & & \\
\hline \multirow[t]{2}{*}{ CZ681946 } & $(\mathrm{CTT})_{4}$ & F: TAATCCCATTCCGTTGTCGT & 45 & 256 & - & + & Odeny et al. (2007) \\
\hline & & R: CCCAGGAAGAGATGAGACCA & & & & & \\
\hline \multirow[t]{2}{*}{ CZ681968 } & $(\mathrm{ATT})_{4}$ & F: CAGGATTTTAATGGATTCTGCAA & 45.5 & 280 & - & + & Odeny et al. (2007) \\
\hline & & R: GGGTGAATACTATTTAAAAGGATA & & & & & \\
\hline \multirow[t]{2}{*}{ CZ681969 } & $(\mathrm{ACT})_{4}$ & F: ATCCCAGACTTCATAGGGAGATAG & 57.5 & 200 & - & + & Odeny et al. (2007) \\
\hline & & R: GTCTAGTCCCAGGTACAAAGAGGT & & & & & \\
\hline \multirow[t]{2}{*}{ CZ681961 } & $(\mathrm{AGA})_{10}$ & F: ATGGGCATGGTAGAGGAGGT & 47 & 198 & - & + & Odeny et al. (2007) \\
\hline & & R: CGCTCATCATCGTCATCAAA & & & & & \\
\hline
\end{tabular}


Table 1-Continuation.

\begin{tabular}{|c|c|c|c|c|c|c|c|}
\hline \multirow[t]{2}{*}{ CZ681943 } & $\begin{array}{l}(\mathrm{GAT})_{5} \\
(\mathrm{GAT})_{4} \\
\left(\mathrm{GAT}{ }_{4}\right.\end{array}$ & F: TGGGCATGGTAGAGGAAGTT & 46 & 186 & - & + & Odeny et al. (2007) \\
\hline & & R: CGTCATGAAGCAACAGGAGA & & & & & \\
\hline \multirow[t]{2}{*}{ CZ681977 } & $(\mathrm{CA})_{7}$ & F: ACCTTGCTTGTTTCGCTTTT & 46 & 148 & - & + & Odeny et al. (2007) \\
\hline & & R: AAGGGAGGTGGACTACAAGGA & & & & & \\
\hline \multirow[t]{2}{*}{ CZ681979 } & $(\mathrm{GT})_{7}$ & F: GTGAGTGAGAGTGAGTGTATTTGT & 60 & 200 & - & + & Odeny et al. (2007) \\
\hline & & R: GCTCTGATGCCAAATGTTGA & & & & & \\
\hline \multirow[t]{2}{*}{ CZ681998 } & $(\mathrm{TC})_{6}$ & F: ACAAATCCGGTGACCCATAA & 60 & 206 & - & + & Odeny et al. (2007) \\
\hline & & R: CCGAGAACAAAAACATTGAACA & & & & & \\
\hline \multirow[t]{2}{*}{ CZ682005 } & $(\mathrm{AC})_{6}$ & F: TGTATGTTCGTTTAGAGGCTTCC & 56 & 200 & - & + & Odeny et al. (2007) \\
\hline & & R: GCCCCTTTTCACTTTTCTCA & & & & & \\
\hline \multirow[t]{2}{*}{ CZ682009 } & $(\mathrm{TG})_{7}$ & F: AGCCACTTAATAACCAAGCCTTTT & 60 & 258 & - & + & Odeny et al. (2007) \\
\hline & & R: GTGTATGCTTTACTTGCTTTCCTTT & & & & & \\
\hline \multirow[t]{2}{*}{ CZ682011 } & $(\mathrm{GT})_{7}$ & F: AAATTCACCACCATGATCCAA & 45 & 196 & - & + & Odeny et al. (2007) \\
\hline & & R: TCTTCACTTCCGAGACACAACT & & & & & \\
\hline
\end{tabular}

Tropics (ICRISAT) (Table 2). The inbred lines have distinct morphological characteristics such as color of the stem, flowers, seeds and pods. These inbred lines were obtained from selfing of genotypes introduced from ICRISAT and have been incorporated to the breeding programs at Embrapa. In addition, cross-amplification evaluations were made using two other legume species: Phaseolus vulgaris (CAL-143, IAC-UNA, BAT-93 and JALO-EEP558 varieties) and Vigna unguiculata ("Fradinho" cultivar), both from the germplasm collection of the Agronomic Institute of Campinas (IAC) (Campinas, SP, Brazil).

Genomic DNA was extracted from freeze-dried leaf samples using the cetyltrimethyl ammonium bromide (CTAB) method with modifications (Faleiro et al., 2003). DNA samples were quantified by comparison with known quantities of $\lambda$ phage DNA on a $1 \%$ agarose gel.

The PCR was carried out in a total reaction volume of $25 \mu \mathrm{L}$ containing $0.5 \mathrm{ng}$ of DNA template, $0.8 \mu \mathrm{M}$ of each forward and reverse primers, $100 \mu \mathrm{M}$ of each dNTP (MBI Fermentas), $1.5 \mathrm{mM} \mathrm{MgCl}_{2}, 10 \mathrm{mM}$ Tris- $\mathrm{HCl}, 50 \mathrm{mM} \mathrm{KCl}$ and $0.5 \mathrm{U}$ Taq DNA Polymerase (Invitrogen). All PCR amplifications were performed in a PTC-200 thermal cycler (MJ Research, Waltham, MA/USA) using the following conditions: $94^{\circ} \mathrm{C}$ for 1 min followed by 30 cycles of $94^{\circ} \mathrm{C}$ for 1 min, specific annealing temperature for $1 \mathrm{~min}, 72^{\circ} \mathrm{C}$ for 1 $\mathrm{min}$, and a final extension of $72^{\circ} \mathrm{C}$ for $5 \mathrm{~min}$. Amplification products were genotyped by electrophoresis on $6 \%$ denaturing polyacrylamide gels in $1 \mathrm{X}$ TBE buffer using a 10 bp ladder (Invitrogen) as a standard size. The DNA fragments were visualized by silver staining according to Creste et al. (2001).

The polymorphism information content (PIC) values were calculated for estimates of marker informativeness according to the equation of Botstein et al. (1980),

$$
\text { PIC }=1-\sum_{i=1}^{n} f_{i}^{2}-\sum_{i=1}^{n-1} \sum_{j=i+1}^{n} 2 f_{i}^{2} f_{j}^{2}
$$

where $f_{i}$ is the frequency of the $i^{\text {th }}$ allele, $f_{i}$ is the frequency of the $\mathrm{j}^{\text {th }}$ allele and the summation extends over $\mathrm{n}$ alleles. In order to compare marker efficiencies in varietal identification, the discriminating power (D) was estimated for each primer based on the formula,

$$
D_{k}=1-\sum_{j-1}^{1} P_{j} \frac{N p_{j}-1}{N-1}
$$

where $\mathrm{N}$ is the number of individuals and $\mathrm{p}^{\mathrm{j}}$ is the frequency of the $j^{\text {th }}$ pattern (Tessier et al., 1999).

The observed heterozygosity $\left(\mathrm{H}_{\mathrm{O}}\right)$ and the expected heterozygosity $\left(\mathrm{H}_{\mathrm{F}}\right)$ were analyzed using the GDA software (Lewis and Zaykin, 2002). Genetic distance was calculated from microsatellite marker data using modified Roger's genetic distances. A genetic distance matrix was estimated using tools for genetic population analysis (TFPGA $\vee 1.3$ ) (Miller, 1997). Cluster analysis was performed using the neighbor-joining (NJ) method with the DARwin v. 5.0.157 software (Perried and Jacquemound-Collet, 2006). The reliability of the generated dendrogram was also tested by bootstrap analysis using the $\mathrm{BooD}$ program with 1000 iterations (Coelho, 2002). The software STRUCTURE version 2.2 (Pritchard et al., 2000) was used to generate a Bayesian inference of the structure of the populations. By this method, a model of $K$ populations is assumed and samples are grouped in order to minimize linkage disequilibrium and to maximize conformity to Hardy-Weinberg equilibrium across all analyzed loci. As a preliminary step, analysis was performed a single time for each $K$ value ranging from 2 to 20 . Each run was performed using the admixture model and 
Table 2 - Information of Cajanus cajan, Phaseolus vulgaris and Vigna unguiculata genotypes evaluated with microsatellite markers.

\begin{tabular}{|c|c|c|c|c|c|c|c|c|}
\hline $\begin{array}{l}\text { Sample } \\
\text { Code }\end{array}$ & $\begin{array}{c}{ }^{(1)} \text { Genotype } \\
\text { ID }\end{array}$ & $\begin{array}{l}\text { Genetic } \\
\text { Origin }\end{array}$ & $\begin{array}{l}\text { Sample } \\
\text { Code }\end{array}$ & $\begin{array}{c}\text { Genotype } \\
\text { ID }\end{array}$ & $\begin{array}{l}\text { Genetic } \\
\text { Origin }\end{array}$ & $\begin{array}{c}\text { Sample } \\
\text { Code }\end{array}$ & $\begin{array}{c}\text { Genotype } \\
\text { ID }\end{array}$ & $\begin{array}{c}\text { Genetic } \\
\text { Origin }\end{array}$ \\
\hline 1 & G1m-95 & (2) ECS & 29 & G106 & India & 57 & G151 & India \\
\hline 2 & G3 & Brazilian Cultivar & 30 & G108-99 & ECS & 58 & G154 & Bangladesh \\
\hline 3 & G05-94 & ECS & 31 & G109 & ECS & 59 & G154-95 & ECS \\
\hline 4 & G06-95 & ECS & 32 & G112 & India & 60 & G158 & India \\
\hline 5 & G8-95 & ECS & 33 & G114 & India & 61 & G165 & India \\
\hline 6 & G9m & ECS & 34 & G115 & India & 62 & G166 & India \\
\hline 7 & G10-94 & ECS & 35 & G116 & India & 63 & G167-97 & ECS \\
\hline 8 & G17c-94 & ECS & 36 & G118 & $\mathrm{ECS}$ & 64 & G168 & India \\
\hline 9 & G18-95 & ECS & 37 & G119 & ECS & 65 & G168-99 & ECS \\
\hline 10 & G19m-95 & ECS & 38 & G120 & India & 66 & G169 & India \\
\hline 11 & G21-99 & ECS & 39 & G121-99 & ECS & 67 & G171 & India \\
\hline 12 & G27 & India & 40 & G123 & ECS & 68 & G174 & India \\
\hline 13 & G27-94 & ECS & 41 & G124 & India & 69 & G176 & n.a. \\
\hline 14 & G29b-94 & ECS & 42 & G124-95 & $\mathrm{ECS}$ & 70 & G184-97 & ECS \\
\hline 15 & $\mathrm{G} 29 \mathrm{~m}-94$ & ECS & 43 & G126 & India & 71 & G186-98 & ECS \\
\hline 16 & G30 & India & 44 & G127 & $\mathrm{ECS}$ & 72 & G197 & India \\
\hline 17 & G39-94 & ECS & 45 & G128 & India & 73 & G198 & India \\
\hline 18 & G40-95 & ECS & 46 & G131 & India & 74 & No 314 & ${ }^{(3)}$ Brazilian - IZ \\
\hline 19 & G47-94 & ECS & 47 & G135 & India & 75 & INPA & Amazônia \\
\hline 20 & G48-95 & ECS & 48 & G137 & India & 76 & FAVA LARGA & Brazilian Gultivar \\
\hline 21 & G57-95 & ECS & 49 & G137-99 & $\mathrm{ECS}$ & 77 & ANÃO & Brazilian Cultivar \\
\hline 22 & G58 & ECS & 50 & G138 & ECS & 78 & CAL-143 & (4) P. vulgaris - IAC \\
\hline 23 & G59-95 & ECS & 51 & G141 & India & 79 & IAG-UNA & P. vulgaris - IAC \\
\hline 24 & G66-95 & ECS & 52 & G142 & India & 80 & BAT-93 & P. vulgaris - IAC \\
\hline 25 & G100 & Bangladesh & 53 & G142-95 & $\mathrm{ECS}$ & 81 & JALO-EEP558 & P. vulgaris - IAC \\
\hline 26 & G101 & India & 54 & G148 & India & 82 & FRADINHO & V. unguiculata - IAC \\
\hline 27 & G101-97 & ECS & 55 & G149 & India & & & \\
\hline 28 & G104 & India & 56 & G149-99 & $\mathrm{ECS}$ & & & \\
\hline
\end{tabular}

${ }^{1}$ Genotype ID: Unidade de Execução de Pesquisa de Âmbito Estadual (UEPAE). ${ }^{2}$ ECS: Embrapa Cattle-Southeast. ${ }^{3} \mathrm{IZ}:$ Institute of Animal Husbandry. ${ }^{4} \mathrm{IAC}$ : Agronomic Institute of Campinas.

1000 replicates for burn-in and 10,000 replicates during analysis. The most probable number of $K$ was calculated based on Evanno et al. (2005) using an ad hoc statistic $\Delta K$, which represents the rate of change in log probability of the data between successive $K$ values rather than the log probability of the data.

\section{Results and Discussion}

Of the 43 microsatellite markers, 16 were polymorphic (Table 3). A total of 83 putative alleles were obtained from the 16 microsatellite markers. The number of alleles ranged from 2 to12, with an average of 5.1 alleles per locus (Table 3). Screening of 77 pigeonpea genotypes with these 16 markers indicated low polymorphism information content. The PIC values ranged from 0.11 to 0.80 with an average of 0.49 . The $\mathrm{D}$ values ranged from 0.23 to 0.91 with an average of
0.58. The highest PIC and D values ware found in locus CZ681938a which contains 8 alleles. The observed $\left(\mathrm{H}_{\mathrm{O}}\right)$ and expected heterozygosity $\left(\mathrm{H}_{\mathrm{F}}\right)$ values ranged from 0.01 to 0.53 (average 0.25) and 0.01 to 0.82 (average 0.47), respectively, indicating high heterozygote deficiency. The low variability in these collections may be due to a narrow genetic base of the original germplasm collection or pre-selection of these genotypes based on agronomic characteristics, mainly related to the production of dry matter (Godoy et al., 2004).

All polymorphic markers were tested for cross-amplification in P. vulgaris (CAL-143, IAC-UNA, BAT-93 and JALOEEP558) and $V$. unguiculata (Fradinho) (Table 4). Thirteen microsatellite markers (CZ445540, CZ445530, AJ306901, AJ312887, AJ312891, AJ312892, AJ312893, AJ312894, AJ312895, CZ681930, CZ681938a, CZ681938b and CZ681983) amplified in at least one bean species. Six markers (CZ445530, CZ681983, AJ312891, AJ312893, AJ312895 
Table 3 - Characteristics of pigeonpea microsatellite loci, including number of alleles, $\mathrm{PIC}, \mathrm{D}, \mathrm{H}_{\mathrm{O}}$ and $\mathrm{H}_{\mathrm{E}}$ values.

\begin{tabular}{lccccc}
\hline GenBank Accession no. & ${ }^{(1)}$ Alelle number & ${ }^{(2)} \mathrm{PIC}$ & ${ }^{(3)} \mathrm{D}$ & ${ }^{(4)} \mathrm{H}_{\mathrm{O}}$ & ${ }^{(5)} \mathrm{H}_{\mathrm{E}}$ \\
\hline CZ445531 & 2 & 0.29 & 0.36 & 0.01 & 0.01 \\
CZ445540 & 2 & 0.29 & 0.35 & 0.33 & 0.27 \\
CZ445530 & 2 & 0.11 & 0.23 & 0.01 & 0.10 \\
AJ306901 & 2 & 0.32 & 0.41 & 0.19 & 0.30 \\
AJ312887 & 4 & 0.51 & 0.62 & 0.20 & 0.52 \\
AJ312891 & 4 & 0.32 & 0.43 & 0.29 & 0.25 \\
AJ312892 & 5 & 0.49 & 0.56 & 0.28 & 0.51 \\
AJ312893 & 12 & 0.61 & 0.72 & 0.42 & 0.55 \\
AJ312894 & 7 & 0.69 & 0.73 & 0.36 & 0.72 \\
AJ312895 & 5 & 0.60 & 0.75 & 0.29 & 0.66 \\
CZ681930 & 6 & 0.66 & 0.78 & 0.29 & 0.70 \\
CZ681938a & 8 & 0.80 & 0.91 & 0.53 & 0.82 \\
CZ681938b & 8 & 0.68 & 0.78 & 0.32 & 0.71 \\
CZ682017a & 8 & 0.74 & 0.82 & 0.21 & 0.77 \\
CZ682017b & 2 & 0.26 & 0.35 & 0.01 & 0.01 \\
CZ681983 & 4 & 0.48 & 0.57 & 0.23 & 0.54 \\
\hline Average & 5.1 & 0.49 & 0.58 & 0.25 & 0.47 \\
\hline
\end{tabular}

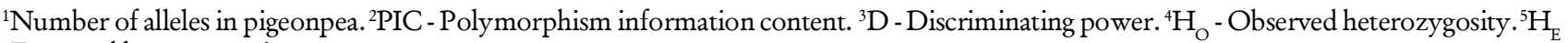
- Expected heterozygosity.

Table 4 - Characteristics of pigeonpea-specific microsatellite markers transferable to Phaseolus vulgaris and Vigna unguiculata.

\begin{tabular}{|c|c|c|c|c|c|}
\hline \multirow{2}{*}{ GenBank Accession no. } & \multirow{2}{*}{$\begin{array}{c}\text { Vigna unguiculata } \\
\text { FRADINHO }\end{array}$} & \multicolumn{4}{|c|}{ Phaseolus vulgaris } \\
\hline & & CAL-143 & IAGUNA & BAT-93 & JALO-EEP558 \\
\hline CZ445531 & - & - & - & & - \\
\hline CZ445540 & $208 / 208$ & $208 / 208$ & $208 / 208$ & $208 / 208$ & $208 / 208$ \\
\hline CZ445530 & $208 / 208$ & $208 / 208$ & $208 / 208$ & $208 / 208$ & $208 / 208$ \\
\hline AJ306901 & $200 / 200$ & $198 / 198$ & $186 / 200$ & $200 / 200$ & $200 / 200$ \\
\hline AJ312887 & $160 / 160$ & - & $160 / 160$ & $160 / 160$ & $160 / 160$ \\
\hline AJ312891 & $180 / 206$ & $206 / 206$ & $206 / 206$ & $206 / 206$ & $206 / 206$ \\
\hline AJ312892 & - & $154 / 154$ & $154 / 156$ & $154 / 156$ & - \\
\hline AJ312893 & $130 / 130$ & $128 / 128$ & $128 / 146$ & $128 / 146$ & $130 / 130$ \\
\hline AJ312894 & $166 / 166$ & - & $166 / 166$ & $166 / 166$ & $166 / 168$ \\
\hline AJ312895 & $242 / 242$ & $242 / 242$ & $242 / 242$ & $242 / 242$ & $242 / 242$ \\
\hline CZ681930 & $164 / 164$ & $166 / 166$ & $166 / 166$ & $172 / 172$ & $164 / 164$ \\
\hline CZ681938a & $252 / 252$ & $260 / 260$ & $252 / 252$ & $252 / 252$ & - \\
\hline CZ681938b & $220 / 228$ & $228 / 228$ & $228 / 228$ & $224 / 228$ & - \\
\hline CZ682017a & - & - & - & - & - \\
\hline CZ682017b & - & - & - & - & - \\
\hline CZ681983 & $73 / 73$ & $73 / 73$ & $75 / 75$ & $75 / 75$ & $73 / 73$ \\
\hline
\end{tabular}

Alleles observed for each locus are displayed in base pairs (bp). (-) No amplification.

and CZ681930) were successfully amplified in P. vulgaris and $V$. unguiculata, indicating very good transferability. Non-specific amplification of the loci CZ445531, CZ682017a and CZ682017b was observed between species. Eight markers (AJ306901, AJ312891, AJ312892, AJ312893, AJ312894, CZ681930, CZ681938a and CZ681938b) revealed polymor- phism between the Phaseolus and Vigna genotypes. These results suggest considerable sequence conservation within the primer regions flanking microsatellite loci. The high level of cross-species amplification and the observed polymorphic alleles suggest that they can be used for inter- and intraspecific studies. This level of amplification efficiency is similar to that 
observed by Gepts et al. (2008) and Gupta et al. (2008), where chickpea and Azuki bean microsatellite markers were used to amplify DNA from other related legume species such as Vigna and Phaseolus, respectively.

STRUCTURE analysis coupled with computation of Evanno $\Delta K$ statistics suggested a primary partition of pigeonpea and genotypes of the $P$. vulgaris and $V$. unguiculata into four clusters $(K=4)$. This analysis can help to identify clusters of genetically similar genotypes. Thus, the subpopulations from the STRUCTURE analysis were grouped into four clusters (C): C1, C2, C3, and C4 (Figure 1a). Cluster $\mathrm{C} 1$ is comprised of the 28 pigeonpea genotypes, which were collected in India (G141, G142, G148, G149, G151, G165, G171, G174, G198, G176, NO 314, G168, G149, G166, G197, G158, G137, G126, G119 and G118), Bangladesh (G154) and the Brazilian inbred lines (G154-95, G142-95, G149-99, G184-97, G168-99, G167-97 and G108-
99). Cluster C2 includes 18 pigeonpea Brazilian inbred lines obtained from the breeding program of Embrapa CattleSoutheast (G1m-95, G05-94, G06-95, G8-95, G9m, G10-94, G17c-94, G19m-95, G27-94, G29b-94, G47-94, G48-95, G3994, G18-95, G40-94, G57-95 and G58) the cultivar G3Guandu Mandarim and 2 pigeonpea genotypes from India (G30 and G27). These Brazilian inbred lines were selected for use in crop-livestock integrated systems and reclaiming degraded pastures. The field data confirmed that these genotypes are closely related. Cluster C3 consisted of 26 pigeonpeas, which were collected in India (104, G114, G120, G124, G116, G135, G112, G115, G101, G106, G131, G169 and G128), Bangladesh (G100) and the Brazil inbred lines (G124-95, G121-99, G101-97, G21-99, G137-99, G109, G123, G127, G138, G59-95, G66-95 and G29m-94). Clusters C1 and C3 had mixed origins (India, Bangladesh and Brazil inbred lines). These results indicate the presence of

a

C1

C2
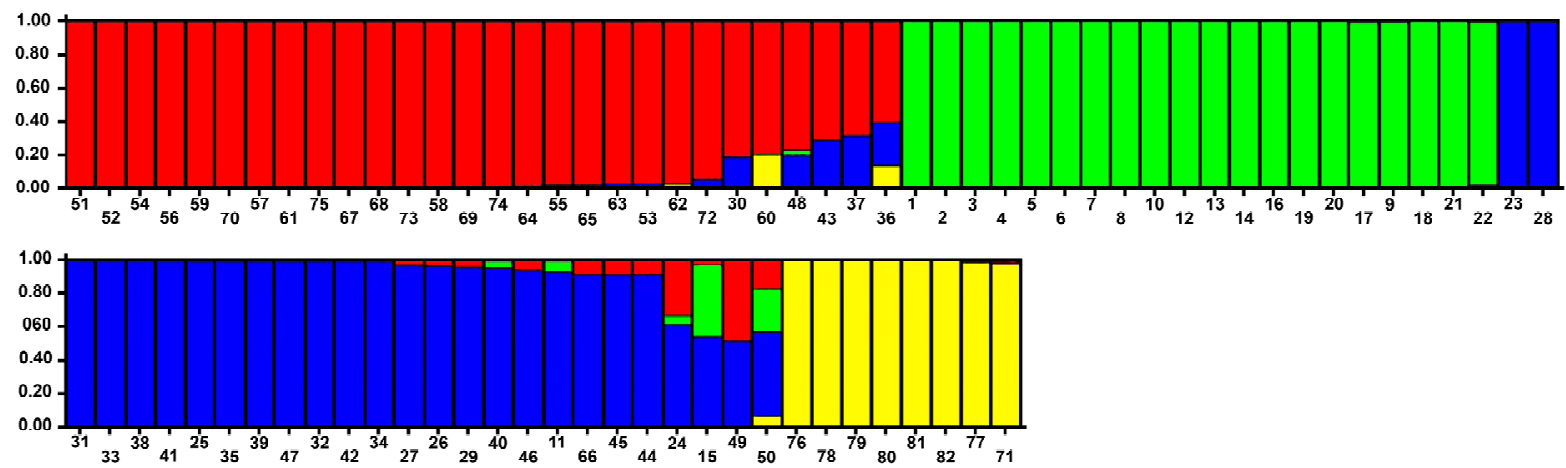

C3

C4

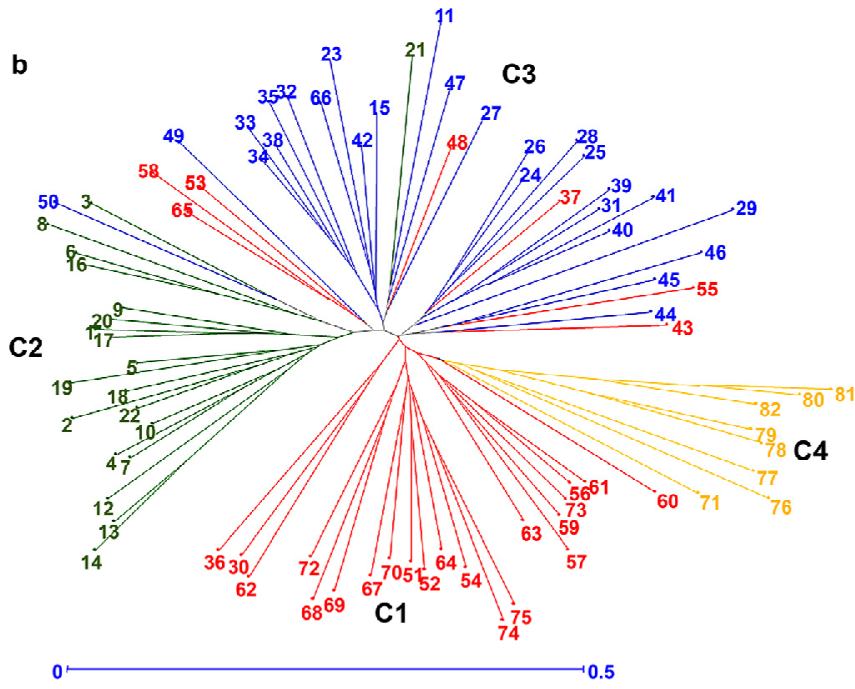

Figure 1 - Genetic diversity of pigeonpea genotypes and cross-species amplification between Phaseolus vulgaris and Vigna unguiculata. a Population structure analysis. Each genotype is represented by a thin vertical segment, which can be partitioned into $K$ colored segments that represent the individual estimated membership to the $K$ cluster. Membership coefficients obtained at the optimal $K$ value ( $K=4$ clusters). b Neighbor-joining tree analysis. The numbers at the tip of tree branches indicate the accession number. The colors of the bar and the tree branch indicate the 4 groups identified through the STRUCTURE program $(C 1=$ red, C2 $=$ green, C3 = blue and C4 = yellow). 
different gene pools among these clusters. Cluster C4 contained two pigeonpea cultivars (Fava Larga and Anão), the inbred line G186-98 and the four varieties of $P$. vulgaris (CAL-143, IAC-UNA, BAT-93 and JALO-EEP558) and one $V$. unguiculata cultivar (Fradinho).

The phylogenetic NJ tree, which was constructed based on the modified Roger's genetic distance matrix, was colored according to STRUCTURE results (Figure 1b). Furthermore, a strong tendency of correspondence between the Bayesian clusters in the NJ tree was observed. Clusters C1 and C3 comprised the pigeonpea genotypes from India, Bangladesh and some Brazilian inbred lines. Cluster $\mathrm{C} 1$ include $18 \mathrm{Bra}-$ zilian inbred lines. Cluster $\mathrm{C} 4$ includes the 2 cultivars, the G186-98 Brazilian inbred line of the pigeonpea and all genotypes of Phaseolus and Vigna. Genotypes of pigeonpea which were self-fertilized (by controlled pollination, and subsequently selected in order to obtain inbred lines) grouped together (G27 and G27-94, G168 and G168-99, G154 and G154-95, G149 and G149-99, G142 and G142-95, G124 and G124-95, G101 and G101-97), except G137 and G137-99. The pigeonpea genotype G137-99 presented a heterozygote profile. Although pigeonpea is considered an autogamous species, in the presence of pollinators, the cross-pollination can occur, ranging from $3 \%$ to $26 \%$. Consequently, a percentage of heterozygous strains can be observed, even if it is a low percentage (Reddy et al., 2004). The bootstrap value of the center point of the group $(82.0 \%)$ indicates the robustness of the genetic relationship depicted by the dendrogram (Figure 1b). The genetic distances among the 77 genotypes of pigeonpea ranged from 0.09 to 0.62 with an average of 0.39 . The lower genetic distances were found among the genotypes of cluster C2, such as G06-95 and G9m (0.09). These two genotypes have similar stem color (green) and thickness $(10 \mathrm{~mm})$ (Godoy et al., 2004; Provazi et al., 2007). The largest genetic distances were found among the genotypes G1m-95 (cluster 2) and G158 (0.62) (cluster 1). Genetic distances between clusters $\mathrm{C} 1$ and $\mathrm{C} 3$ were higher than the $\mathrm{C} 2$ cluster revealing moderate diversity among these genotypes. The cultivars Fava Larga and Anão were grouped in a distinct cluster (C4) with 0.42 genetic distance between them. The cluster analysis based on modified Roger's genetic distances shows the narrowing of the genetic basis among genotypes.

Knowledge of the genetic diversity in germplasm collections is fundamental for further breeding programs to fully exploit existing diversity by genotypes selection. As evident from the clustering of genotypes, it is clear that these microsatellite markers are efficacious. The pigeonpea is an important crop of the Phaseoleae tribe, which has limited genomic resources. As microsatellite markers are highly polymorphic, reproducible, co-dominant in nature and distributed throughout the genome, they have become the ideal marker system for genetic analysis and breeding applications.

\section{Conclusions}

The microsatellite markers revealed low genetic diversity among genotypes of pigeonpea, especially between the Brazilian inbred lines selected for use in crop-livestock integrated systems and reclaiming degraded pastures. The modified Roger's genetic distances revealed the presence of genetically close genotypes.

Pigeonpea-specific microsatellite markers were transferable to $P$. vulgaris and $V$. unguiculata. The transferable loci exhibited polymorphism among some genotypes. Transferability studies of microsatellite loci from other cultures can be highly advantageous.

\section{Acknowledgements}

To FAPESP, Project 05/51010-0) and fellowship to Sousa, A. C. B. (06/52953-8), and to CNPq for the fellowship awarded to Souza, A. P.

\section{References}

Burns, M.J.; Edwards, K.J.; Newbury, H.J.; Ford-Lloyd, B.V.; Baggott, C.D. 2001. Development of simple sequence repeat (SSR) markers for the assessment of gene flow and genetic diversity in pigeonpea (Cajanus cajan). Molecular Ecology Notes 1: 283-285.

Botstein, D.; White, R.L.; Skolnick, M.; Davis, R.W. 1980. Construction of a genetic linkage map in man using restriction fragment length polymorphisms. American Journal of Human Genetics 32: 314331.

Coelho, A.S.G. 2002. BooD: assessment of errors associated with estimates of distances/genetic similarities across the bootstrap procedure with variable number of markers. UFG, Goiânia, GO, Brazil (in Portuguese). (CD-ROM).

Creste, S.; Tulmann Neto, A.; Figueira, A. 2001. Detection of single sequence repeat polymorphisms in denaturing polyacrylamide sequencing gels by silver staining. Plant Molecular Biology Reporter 19: 299-306.

Evanno, G.; Regnaut, S.; Goudet, J. 2005. Detecting the number of clusters of individuals using the software STRUCTURE: a simulation study. Molecular Ecology 18: 2611-2620.

Faleiro, F.G.; Faleiro, A.S.G.; Cordeiro, M.C.R. Karia, T.K. 2003. DNA extraction methodology from leaves of native central Brazilian region species to operate molecular analysis. Boletim Técnico da Embrapa Cerrados, Brasília, DF, Brazil 92: 1-5. (in Portuguese).

Gaitàn-Solì, E.; Duque, M.C.; Edwards, K.J.; Tohme, J. 2002. Microsatellite repeats in common bean (Phaseolus vulgaris): isolation, characterization, and cross-species amplication in Phaseolus ssp. Crop Science 42: 2128-2136.

Gepts, P.; Francisco, J.L.A.; Everaldo, B.; Matthew, W.B.; Rosana, B.; William, B.; Incoronata, G.; Gina, H.; James, K.; Patricia, L.; Phillip, M.; Maeli, M.; Peter, P.; Andrea, P.H.; Timothy, P.; Federico, S.; Francesa, S.; Kangfu, Y. 2008. Genomics of Phaseolus beans, a major source of dietary protein and micro-nutrients in the tropics. p. 113-143. In: Moore, P.H.; Ming, R., eds. Genomics of tropical crop plants. Springer, NewYork, NY, USA.

Gupta, S.K.; Souframanien, J.; Gopakrishna, T. 2008. Construction of a genetic linkage map of black gram, Vigna mungo (L.) Hepper, based on molecular markers and comparative studies. Genome 51: 628-637.

Godoy, R.; Batista, L.A.R.; Souza, F.H.D.; Primavesi, A.C. 2003. Description of selected Pigeon-pea (Cajanus cajan (L.) Millsp) pure lines. Revista Brasileira de Zootecnia 32: 546-555. (in Portuguese, with abstract in English).

Godoy, R.; Fushita, A.T.; Dübbern De Souza, F.H. 2004. Description of eleven pigeonpea pure lines selected in São Carlos, SP. Revista Brasileira de Zootecnia 33: 2206-2213. (in Portuguese, with abstract in English).

Godoy, R.; Batista, L.A.R.; Negreiros, G.F. 1994. Agronomic evaluation and selection of germplasm of pigeonpea forage (Cajanus cajan (L.) Millsp). Revista Brasileira de Zootecnia 23: 742-749. (in Portuguese, with abstract in English). 
Godoy, R.; Batista, L.A.R.; Negreiros, G.F. 1995. Agronomic evaluation of pigeonpea forage (Cajanus cajan (L.) Millsp). Revista Brasileira de Zootecnia 23: 730-742. (in Portuguese, with abstract in English).

Godoy, R.; Batista, L.A.R.; Negreiros, G.F. 1997. Agronomic evaluation and selection of germplasm of pigeonpea forage (Cajanus cajan (L.) Millsp from the India. Revista Brasileira de Zootecnia 26: 447453. (in Portuguese, with abstract in English).

Lewis, P.; Zaykin, D. 2002. Genetic Data Analysis (GDA): computer program for the analysis of allelic data: version 1.1 (d12). Available at: http://alleyn.eeb.uconn.edu/gda/. [Accessed Sep. 22, 2009].

Miller, M.P. 1997. Tools for Population Genetic Analysis (TFPGA) 1.3: A windows program for the analysis of allozyme and molecular population genetic data. (Computer software distributed by author).

Odeny, D.A.; Ayashree, B.; Ferguson, M.; Hoisington, D.; Crouch, J.; Gebhardt. 2007. Development, characterization and utilization of microsatellite markers in pigeonpea. Plant Breeding 126: 130-136.

Perrier, X.; Jacquemound-Collet, J.P. DARwin software. Available at: http://www.darwin.cirad.fr/darwin. 2006. [Accessed Jul. 12, 2008].

Pritchard, J.K.; Stephens, M.; Donnelly, P. 2000. Inference of population structure using multilocus genotype data. Genetics 155: 945-959.

Provazi, M.; Camargo, L.H.G.; Santos, P.M.; Godoy, R. 2007. Botanical description of selected pigeonpea pure lines. Revista Brasileira de Zootecnia 36: 328-334. (in Portuguese, with abstract in English).
Reddy, L.J.; Chandra, S.; Pooni, H.; Branmel, P.J. 2004. Rate of outcrossing in pigeonpea under intercropped conditions. p. 324-502. In: Bramel, P.J., ed. Assessing the risk of losses in biodiversity in traditional cropping systems: a case study of pigeonpea in Andhra Pradesh. International Crops Research Institute for the Semi-Arid Tropics. Patancheru, Andhra Pradesh, India.

Reddy, L.J.; Upadhyaya, H.D.; Gorda, C.L.L.; Sube, S. 2005. Development of core collection in pigeonpea [Cajanus cajan (L.) Millspaugh] using geographic and qualitative morphological descriptors. Genetic Resources and Crop Evolution 52: 1049-1056.

Tessier, C.; David, J.; Boursiquot, P.; Charrieir, A.J.M. 1999. Optimizations of the choice of molecular markers for varietal identification in Vitis vinifera L. Theoretical and Applied Genetics 98: 171-177.

Varshney, R.K.; Graner, A.; Sorrells, M.E. 2005. Genic microsatellite markers in plants: features and applications. Trends Biotechnology 23: $48-55$.

Received July 05,2010

Accepted October 20, 2010 